ks. Stanisław Wronka

\title{
2. Walne Zebranie Stowarzyszenia Biblistów Polskich i 43. Sympozjum Biblistów Polskich (Kowicz, 20-22 września 2005)
}

Doroczne spotkanie biblistów polskich odbyło się tym razem w Łowiczu, w budynkach diecezjalnego seminarium duchownego. Wieczorem 20 września miało miejsce 2. Walne Zebranie Stowarzyszenia Biblistów Polskich. Uroczystego otwarcia dokonał jego przewodniczący ks. prof. Waldemar Chrostowski, który przedstawił stan rozwijającego się prężnie stowarzyszenia (na dzień 11 sierpnia 2005 liczyło ono 211 członków zwyczajnych) i najważniejsze wydarzenia od ubiegłorocznego walnego zebrania, m.in. otwarcie strony internetowej stowarzyszenia 18 maja 2005, w 85. rocznicę urodzin Jana Pawła II (www.sbp.net.pl), do odwiedzania której zachęcił wszystkich. Wspomniał również zmarłego 2 kwietnia 2005 Ojca Świętego i oddał mu hołd, jak również zmarłym niedawno biblistom: ks. prof. Andrzejowi Strusowi SDB (12 czerwca 2005) i ks. drowi hab. Marianowi Wolniewiczowi (14 lipca 2005). Następnie skarbnik ks. prof. Tomasz Jelonek złożył sprawozdanie dotyczące stanu materialnego stowarzyszenia, które po dyskusji zostało przyjęte w głosowaniu. W dalszych głosowaniach przyjęto również regulamin walnego zebrania SBP i regulamin zarządu SBP. Na wniosek zarządu honorowe członkostwo stowarzyszenia otrzymał ks. prof. Ryszard Rubinkiewicz SDB, który jako przewodniczący Sekcji Biblistów Polskich powołanej przez Konferencję Episkopatu Polski rozpoczął starania o przekształcenie jej w stowarzyszenie, doprowadzone do szczęśliwego końca przez jego następcę ks. prof. Waldemara Chrostowskiego 5 grudnia 2003. W dalszej kolejności dyskutowano nad regulaminem członkostwa zwyczajnego SBP, regulaminem członkostwa honorowego SBP i regulaminem członkostwa stowarzyszonego SBP. Ksiądz przewodniczący przypomniał o zgłaszaniu kandydatów do dorocznej nagrody stowarzyszenia „w uznaniu za wybitne osiągnięcia w dziedzinie badań biblijnych i duszpasterstwa biblijnego" ustanowionej na pierwszym zebraniu plenarnym. Po długiej dyskusji, w czasie której zgłoszono szereg ciekawych wniosków, ks. prof. Waldemar Chrostowski zamknął 2. Walne Zebranie Stowarzyszenia Biblistów Polski. 
43. Sympozjum Biblistów Polski rozpoczęło się 21 września mszą świętą koncelebrowaną o godz. $7.30 \mathrm{w}$ kaplicy seminaryjnej pod przewodnictwem biskupa łowickiego Andrzeja F. Dziuby. Po śniadaniu ks. prof. Waldemar Chrostowski dokonał otwarcia sympozjum. Zgodnie z ustaleniami w czasie zeszłorocznego sympozjum w Gdańsku Oliwie tegoroczne obrady zostały poświęcone w całości związkom Jana Pawła II z Biblią: Ioannes Paulus II - papa Sacrae Paginae (Jan Paweł II - papież Pisma Świętego). Wszystkie wystąpienia starały się ukazać podejście Ojca Świętego do Biblii, wątki poruszane przez niego najczęściej oraz inspiracje płynące z jego postawy dla biblistyki.

I sesji przewodniczył ks. prof. Rubinkiewicz (KUL Lublin), a złożyły się na nią dwa referaty: ks. prof. Henryk Witczyk, zastępca przewodniczącego Stowarzyszenia Biblistów Polskich, mówił na temat Jan Pawet II - promotor odnowy biblijnej, natomiast nestor biblistów polskich ks. prof. Józef Kudasiewicz przybliżył Chrystocentryczna hermeneutykę biblijna Jana Pawła II.

Po dyskusji i małej przerwie na kawę odbyła się II sesja, którą poprowadził ks. prof. Julian Warzecha (UKSW Warszawa). Była ona krótka, zawierała tylko jeden referat ks. dra Mariusza Szmajdzińskiego Prawda jako Mądrość objawiona w świetle encykliki Jana Pawta II „Fides et ratio”.

Po jego wystąpieniu był czas na dyskusję oraz komunikaty licznych wydawnictw obecnych ze swymi publikacjami na sympozjum. Wśród nich na uwagę zasługuje przede wszystkim pierwszy tom nowego wydania Biblii w języku polskim Pismo Święte Nowego Testamentu i Psalmy. Najnowszy przekład z języków oryginalnych z komentarzem, opracował Zespół Biblistów Polskich z inicjatywy Towarzystwa Świętego Pawła, Edycja Świętego Pawła, Częstochowa 2005, który każdy uczestnik Sympozjum otrzymał w podarunku od wydawnictwa. Współautorzy prosili o propagowanie tego przekładu i sugerowali nawet, że można by go używać w liturgii, ponieważ jest bardziej zrozumiały niż Biblia Tysiąclecia. Jako kontrargument usłyszeli jednak, że w duszpasterstwie lepiej trzymać się jednej wersji tekstu biblijnego i że powinna nią pozostać właśnie Biblia Tysiaclecia, która zadomowiła się już na dobre w Kościele w Polsce. Z radością powitano też pierwsze dwa tomy Nowego Komentarza Biblijnego wydawanego również przez Edycję Świętego Pawła w Częstochowie: A. Paciorek, Ewangelia wedtug Świętego Mateusza, rozdziaty 1-13. Wstęp, przekład z oryginatu, komentarz, 2005 (Nowy Testament 1.1), i M. Wojciechowski, Księga Tobiasza czyli Tobita. Opowieść o miłości rodzinnej. Wstęp, przekład z oryginału, komentarz, 2005 (Stary Testament 12). Następne tomy tej serii powinny ukazywać się sukcesywnie w niedalekiej przyszłości. Gorzej natomiast przedstawia się sprawa ukończenia komentarzy do Starego Testamentu w ramach serii przygotowywanej od dawna przez KUL, gdyż istnieją trudności ze strony 
Wydawnictwa Pallottinum. Warto również wspomnieć numer 2 „Zeszytów Naukowych Stowarzyszenia Biblistów Polskich”, który był przygotowany dla każdego członka stowarzyszenia. W jego pierwszej części znalazły się dokumenty związane ze Stowarzyszeniem Biblistów Polskich i aktualny wykaz jego członków zwyczajnych, a w drugiej części artykuły, głównie z ubiegłorocznego sympozjum.

Po obiedzie była wspólna fotografia uczestników sympozjum oraz możliwość zwiedzenia pięknej i bogatej w historię katedry łowickiej, w której pochowanych jest dwunastu prymasów Polski, oraz jej najbliższego otoczenia.

Przed rozpoczęciem kolejnej sesji wręczona została bpowi Janowi Bernardowi Szladze z Pelplina księga pamiątkowa w 65. rocznicę urodzin Oto ide, zebrał i opracował ks. W. Chrostowski, Oficyna Wydawnicza „Vocatio", Warszawa 2005 (Ad Multos Annos, 10). Następnie biskup siedlecki Zbigniew Kiernikowski podzielił się refleksjami na temat zakończonego kilka dni wcześniej w Rzymie kongresu zorganizowanego przez Katolicką Federację Biblijną i Papieską Radę ds. Popierania Jedności Chrześcijan z okazji 40. rocznicy uchwalenia soborowej Konstytucji dogmatycznej o objawieniu Bożym Dei verbum. Hasło kongresu brzmiało: Pismo Święte w życiu Kościoła, a wśród jego prelegentów znaleźli się m.in. kard. Walter Kasper, przewodniczący wspomnianej rady, i kard. Carlo Maria Martini. Oprócz bpa Kiernikowskiego, który uczestniczył w kongresie jako przedstawiciel Konferencji Episkopatu Polski, wzięło w nim udział kilku polskich księży, w tym redaktor naczelny „Ruchu Biblijnego i Liturgicznego” ks. prof. Jerzy Chmiel reprezentujący Papieską Akademię Teologiczną w Krakowie.

W czasie III sesji, której przewodniczył ks. dr hab. Waldemar Rakocy CM (KUL Lublin), wygłoszone zostały dwa komunikaty: ks. dr hab. Józef Kozyra mówił o Chrystocentryzmie „Ecclesia in Europa”, a ks. dr Hubert Ordon SDS o Biblijnym tle „Novo millennio ineunte”. Trzeciego komunikatu nie było z powodu nieobecności ks. dra hab. Józefa B. Łacha, który przysłał jedynie swój tekst Wątki antropologii i podmiotowości człowieka w świetle nauczania Jana Pawta II na temat Rdz 2. Ostatnim wystąpieniem w tej sesji był referat ks. dra Karola Dąbrowskiego CSMA Jan Pawet II - głosiciel Ewangelii Apostoła Pawta. W świetle jego referatu widać jasno, że papież nie na darmo nosił imię Pawła; można go śmiało nazwać także Pawłem naszych czasów. Dyskusja zakończyła oficjalne obrady tego dnia.

Po kolacji odbyło się spotkanie zainteresowanych „Dziełem Biblijnym im. Jana Pawła II" erygowanym przez Konferencję Episkopatu Polski. Ks. prof. Witczyk przedstawił statut dzieła, zatwierdzony na okres trzech lat przez 332. zebranie plenarne Konferencji Episkopatu Polski obradujące w Warszawie w dniach 17-18 czerwca 2005, oraz plan działania na najbliższy czas. Wieczorem 
spotkanie było kontynuowane do późnych godzin w przyjacielskiej atmosferze przy rożnie ustawionym w ogrodach seminarium pod rozgwieżdżonym niebem. Według etymologii greckiej bowiem „sympozjum” to zebranie towarzyskie połączone z posiłkiem i występami artystycznymi.

Drugi dzień 43. Sympozjum Biblistów Polskich (22 września) rozpoczął się również o godz. 7.30 mszą świętą koncelebrowaną pod przewodnictwem bpa Zbigniewa Kiernikowskiego. Po śniadaniu przystąpiono do IV sesji prowadzonej przez ks. prof. Michała Czajkowskiego (UKSW Warszawa). W jej trakcie swoje referaty wygłosili: ks. dr Stanisław Wronka na temat Od stowa do rzeczywistości - Jana Pawta II integralna lektura Biblii i ks. dr Roman Bogacz na temat Spotkanie Chrystusa z człowiekiem w twórczości Karola Wojtyły.

Po dyskusji i kawie ks. prof. Tadeusz Brzegowy (PAT Kraków) otworzył V sesję, na którą złożyły się komunikat ks. dra Adama Domańskiego Abraham w nauczaniu Jana Pawta II oraz referat ks. dra Henryka Romanika Wielki Jubileusz Wcielonego Stowa: 2000-2033.

W końcowej dyskusji zastanawiano się nad specyfiką biblistyki polskiej. Niektórzy wyrażali obawę, czy nie poszła ona za bardzo w przekłady prac obcych. Wydaje się jednak, że ta wielka praca translatorska jest potrzebna, aby przybliżyć się do biblistyki światowej i stworzyć bazę dla własnych poszukiwań. Podobnymi drogami rozwijała się biblistyka włoska, należąca dziś do znaczących w świecie. Już w tej chwili prace polskich biblistów zaczynają swoim poziomem konkurować z publikacjami zagranicznymi, a Bibliografia biblistyki polskiej 1945-1999, t. I-II, Poznań 2002, opracowana przez ks. dra Piotra Ostańskiego należy do najlepszych dzieł tego typu. Autor poinformował, że pragnie kontynuować tę pracę i prosił wszystkich o przesłanie wykazów swoich publikacji związanych z Biblią począwszy od roku 2000. Wielu było zgodnych, że na pewno pozytywną cechą polskiej biblistyki jest jej wierność magisterium Kościoła i wrażliwość na problemy duszpasterskie. Proponowano też, aby zmienić nieco profil sympozjów: ograniczyć referaty do kilku, za to bardziej syntetycznych i żywiej prezentowanych, natomiast wprowadzić pracę w grupach wokół tematów bardziej zawężonych. Być może przyszłe 44. Sympozjum Biblistów Polskich będzie już prowadzone w ten sposób. Odbędzie się ono w Kaliszu, w cieniu sanktuarium św. Józefa, w dniach 20-21 września 2006, poprzedzone już tradycyjnie 3. Walnym Zebraniem Stowarzyszenia Biblistów Polskich wieczorem 19 września. Materiały tegorocznego sympozjum zostaną zamieszczone w specjalnym tomie, który ukaże się 2 kwietnia 2006, w pierwszą rocznicę śmierci Jana Pawła II.

Na koniec ks. prof. Waldemar Chrostowski podziękował wszystkim za wkład w przygotowanie tegorocznego sympozjum i za udział w nim. Słowa szczególnej wdzięczności skierował do biskupa łowickiego i seminarium 
duchownego, którzy w tym roku udzielili gościny biblistom polskim. Ich obecność w jakiejś diecezji ubogaca ją, ale wiąże się z niemałym wysiłkiem, by obsłużyć tak wielkie spotkanie. W imieniu wszystkich uczestników ks. prof. Witczyk podziękował ks. prof. Chrostowskiemu za ofiarną i konstruktywną pracę w kierowaniu Stowarzyszeniem Biblistów Polskich i przeprowadzeniu kończącego się sympozjum. Po obiedzie jego uczestnicy rozjechali się do swoich domów.

W 43. Sympozjum Biblistów Polskich wzięło udział około 150 biblistów, wśród których zdecydowaną większość stanowili księża, ale było też czterech biskupów (do wspomnianych trzeba dodać jeszcze biskupa seniora Alojzego Orszulika SAC), a także niemało świeckich, których liczba ciągle wzrasta. Nie zabrakło też przedstawicieli innych wyznań chrześcijańskich. Wspólna refleksja nad podejściem Jana Pawła II do Pisma Świętego dała wszystkim wiele do myślenia i będzie na pewno inspirować do dalszej pracy w jego duchu. Trzeba by podejmować ją nie tylko w pojedynkę, ale także wspólnie z innymi. Sympozja ułatwiają taką współpracę, gdyż ożywiają wzajemne relacje pomiędzy biblistami i ośrodkami biblijnymi w Polsce. 